\title{
Study of Some Heavy Metals and Radioactive Element from Soil Samples, Nyala Area -Sudan
}

\author{
Ismael. A. Wadi ${ }^{1}$, Mubarak Dirar ${ }^{2}$, Ahmed Elhassan ${ }^{3}$ \\ ${ }^{1}$ (Physics Department, Faculty of Education, University of Nyala, Sudan \\ ${ }^{2,3}$ Physics Department, Faculty of Science, Sudan University of Science \& Technology - Sudan
}

\begin{abstract}
In this work X-ray fluorescence (XRF) technique was used to evaluate the soil pollution with heavy metals for 40 surface and sub-surface soil samples ( $0-5 \mathrm{~cm}$ in depth) from various locations to cover the area of Nyala city, Sudan. Concentrations of eleven elements $\mathrm{Cr}, \mathrm{Ni}, \mathrm{Cu}, \mathrm{Zn}, \mathrm{Pb}, \mathrm{Co}, \mathrm{Fe}, \mathrm{Zr}, \mathrm{Y}, \mathrm{Rb}$ and $\mathrm{V}$ were determined. The study established as the data baseline to the major and minor trace elements from study area that has not been investigated before. The elemental concentrations were compared with the normal values and other studies in different locations from the world. The correlation between elements indicates that no pollution exists inside the investigated area. The results indicated that all the samples analyzed are safe in general for the toxicity levels. The results establish a database reference of radioactivity background levels for the study around Nyala city.
\end{abstract}

Keywords: XRF, Heavy metals, Soil samples, Environmental pollution, Nyala area.

\section{Introduction}

Heavy metals are defined as metallic elements that have a relatively high density compared to water [1]. With the assumption that heaviness and toxicity are inter related, heavy metals also include metalloids, such as arsenic, that are able to induce toxicity at low level of exposure [2]. In recent years, there has been an increasing ecological and global public health concern associated with environmental contamination by these metals. Also, human exposure has risen dramatically as a result of an exponential increase of their use in several industrial, agricultural, domestic and technological applications [3].sources of heavy metals in the environment include geogenic, industrial, agricultural, pharmaceutical, domestic effluents, and atmospheric sources [4]. Environmental pollution is very prominent in point source areas such as mining, foundries and smelters, and other metal-based industrial operations $[1,3,4]$.

Heavy metals induced toxicity and carcinogenicity involves many mechanistic aspects, some of which are not clearly elucidated or understood. However, each metal is known to have unique features and physic-chemical properties that confer to its specific toxicological mechanisms of action. This review provides an analysis of the environmental occurrence, production and use, potential for human exposure, and molecular mechanisms of toxicity, genotoxicity, and carcinogenicity of arsenic, cadmium, chromium, lead, and mercury [1, 2, 3, 4]. Measurements and studies of natural radioactivity in soil and rocks are very important to determine the amount of change of the natural background activity with time as a result of any radioactive release; monitoring of any release of radioactivity to the environment is important for environmental protection [5] .

In recent years, attention has been drawn to the development and steady introduction of analytical methods suitable for quantification of thorium and uranium tracers. From the viewpoint of radiation protection, determination of natural radionuclide's such as ${ }^{238} \mathrm{U},{ }^{40} \mathrm{~K}$ and ${ }^{232} \mathrm{Th}$ in soil samples are also important.
Studying the levels of radionuclide distribution in the environment provides essential radiological information $[5,6,7,8]$. As a result of rapid urbanization and industrial development, heavy metal contamination has been threatening human health [9].

A soil pollution assessment becomes very complex when different sources of contamination are present and their products are variably distributed. In these cases, the spatial variability of heavy metal concentrations in soils is basic information for identifying the possible sources of contamination and to delineate the strategies of site remediation. The main objective of this study is to determine the level of soil pollution and assess the heavy metal and trace elements contamination for surface and subsurface soil samples of Nyala Area, and to compare with other studies, whose activity of human lasted few years, being one of the most important metallurgical complexes and representing a great potential of environmental contamination $[5-8,10]$.

\section{Material and Methods}

40 soil Samples were collected during July 2015 and August 2015, at surface level (0-5 cm in depth) from various locations to cover study area, Nyala city is the capital of South Darfur state in the western part of the Sudan. its located at elevation 2,208 feet (673 m) in Darfur region.[11] located at the intersection of longitude 24.53 degrees east and latitude 12.03 degrees north, It is important to note that this area is high density populated and tourisms area. The soil samples were dried, homogenized and sieved at 200 mesh grain size. Pressed powder pellets were prepared to avoid the elements contaminations, heavy metals and trace element analysis of samples by X-Ray fluorescence performed using a Philips PW XU unique, This instrument is connected to a computer system using X-40 program for spectrometry. The trace elements concentrations are calculated from the program's calibration curves which were set up according to international reference materials, (standards). The detection limit is the lowest concentration, and it is function of the level of background noise relative to 


\section{International Journal of Science and Research (IJSR) \\ ISSN (Online): 2319-7064}

Index Copernicus Value (2013): 6.14 | Impact Factor (2014): 5.611

an element signal [12].The distance between each successive

sample about one kilometer.

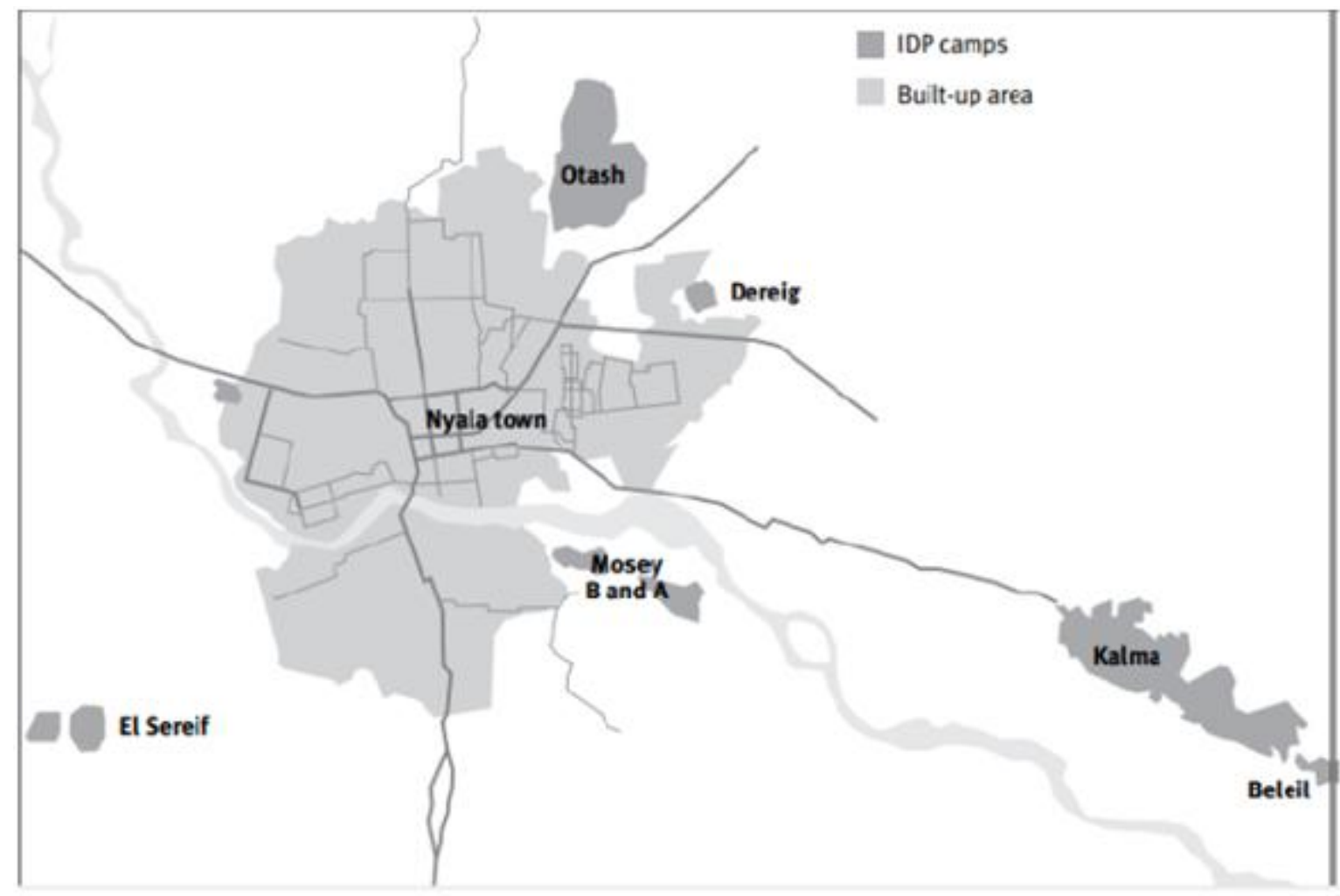

Figure 1: Map of Nyala city, South Darfur state, Sudan [11]

\section{Results and Discussion}

The concentration of heavy metals elements for Nyala area from 24 soil selected samples are presented here:

Table 1: Heavy metals concentration (in ppm) using XRF techniques for some selected soil samples from Nyala city.

\begin{tabular}{|c|c|c|c|c|c|c|c|c|c|c|c|c|c|}
\hline No & Sample & Depth & $\mathrm{Cr}$ & $\mathbf{N i}$ & $\mathrm{Cu}$ & Zn & $\mathbf{P b}$ & Co & $\mathbf{F e}$ & $\mathbf{Z r}$ & $\mathbf{Y}$ & $\mathbf{R b}$ & V \\
\hline 1 & S01E & 0 & 0.012 & 0.007 & 0.008 & 0.033 & 0.008 & 0.007 & 2.880 & 372.820 & 25.660 & 92.290 & 61.590 \\
\hline 2 & S02E & 5 & 0.022 & 0.003 & 0.005 & 0.011 & 0.008 & 0.000 & 1.314 & 198.401 & 10.165 & 89.321 & 65.321 \\
\hline 3 & S05E & 0 & 0.016 & 0.008 & 0.007 & 0.013 & 0.007 & 0.000 & 3.048 & 200.231 & 11.289 & 85.320 & 60.215 \\
\hline 4 & S06E & 5 & 0.028 & 0.002 & 0.002 & 0.004 & 0.003 & 0.000 & 1.023 & 154.254 & 13.967 & 88.321 & 55.321 \\
\hline 5 & S09E & 0 & 0.019 & 0.007 & 0.007 & 0.005 & 0.001 & 0.000 & 0.842 & 198.879 & 14.212 & 83.001 & 50.214 \\
\hline 6 & S10E & 5 & 0.023 & 0.003 & 0.004 & 0.009 & 0.002 & 0.000 & 1.373 & 198.458 & 15.154 & 88.321 & 27.675 \\
\hline 7 & S01W & 0 & 0.015 & 0.007 & 0.004 & 0.004 & 0.002 & 0.000 & 2.471 & 343.733 & 17.146 & 90.812 & 41.761 \\
\hline 8 & S02W & 5 & 0.017 & 0.003 & 0.007 & 0.004 & 0.003 & 0.000 & 1.212 & 200.215 & 14.121 & 55.658 & 41.762 \\
\hline 9 & S05W & 0 & 0.023 & 0.001 & 0.002 & 0.001 & 0.000 & 0.000 & 1.119 & 197.666 & 10.089 & 51.085 & 39.698 \\
\hline 10 & S06W & 5 & 0.017 & 0.004 & 0.001 & 0.001 & 0.000 & 0.000 & 1.084 & 315.635 & 12.980 & 4.713 & 44.226 \\
\hline 11 & S09W & 0 & 0.025 & 0.000 & 0.003 & 0.001 & 0.000 & 0.000 & 1.119 & 105.514 & 9.666 & 8.0756 & 41.666 \\
\hline 12 & S10W & 5 & 0.013 & 0.003 & 0.006 & 0.001 & 0.003 & 0.007 & 2.684 & 198.401 & 11.200 & 154.321 & 36.108 \\
\hline 13 & S01S & 0 & 0.016 & 0.000 & 0.001 & 0.004 & 0.002 & 0.000 & 0.059 & 105.514 & 13.808 & 114.300 & 31.178 \\
\hline 14 & S02S & 5 & 0.019 & 0.003 & 0.002 & 0.004 & 0.004 & 0.000 & 0.847 & 198.401 & 15.128 & 77.326 & 29.640 \\
\hline 15 & S05S & 0 & 9.726 & 3.106 & 0.852 & 0.167 & 0.000 & 0.000 & 29.18 & 171.760 & 13.422 & 68.617 & 39.698 \\
\hline 16 & S06S & 5 & 0.024 & 0.003 & 0.012 & 0.003 & 0.002 & 0.000 & 1.182 & 263.028 & 15.545 & 69.604 & 42.783 \\
\hline 17 & S09S & 0 & 0.023 & 0.000 & 0.051 & 0.001 & 0.001 & 0.000 & 1.017 & 213.277 & 14.321 & 48.759 & 29.640 \\
\hline 18 & S10S & 5 & 0.015 & 0.002 & 0.053 & 0.002 & 0.002 & 0.000 & 1.671 & 699.122 & 28.543 & 56.325 & 43.175 \\
\hline 19 & S01N & 0 & 0.014 & 0.006 & 0.006 & 0.021 & 0.007 & 0.000 & 2.791 & 442.841 & 29.556 & 95.088 & 69.071 \\
\hline 20 & S02N & 5 & 0.027 & 0.008 & 0.002 & 0.004 & 0.002 & 0.000 & 1.892 & 295.127 & 18.947 & 74.986 & 52.745 \\
\hline 21 & S05N & 0 & 0.019 & 0.005 & 0.004 & 0.004 & 0.002 & 0.000 & 1.267 & 215.350 & 16.001 & 56.325 & 69.071 \\
\hline 22 & S06N & 5 & 0.018 & 0.007 & 0.004 & 0.004 & 0.000 & 0.004 & 2.894 & 298.218 & 17.923 & 69.084 & 70.604 \\
\hline 23 & S09N & 0 & 0.026 & 0.004 & 0.001 & 0.001 & 0.002 & 0.000 & 1.541 & 858.960 & 31.22 & 65.324 & 52.908 \\
\hline 24 & S10N & 5 & 0.031 & 0.003 & 0.000 & 0.002 & 0.003 & 0.000 & 1.542 & 215.35 & 15.020 & 56.325 & 50.654 \\
\hline
\end{tabular}

XRF results for the collected soil samples evident the existence of the following elements: $\mathrm{Co}, \mathrm{Fe}$ (major) $\mathrm{Cr}, \mathrm{Ni}$, $\mathrm{Cu}, \mathrm{Zn}, \mathrm{Pb}, \mathrm{Zr}, \mathrm{Y}, \mathrm{Rb}$ and $\mathrm{V}$ (minor).
The average concentrations of heavy metals $\mathrm{Cr}, \mathrm{Cu}, \mathrm{Ni}, \mathrm{Pb}$ and $\mathrm{Zn}$ for more than one measurements of each of the soil samples presented in part per million (ppm) units are given in Table 1 [10]. It was found that $\mathrm{Fe}$ concentrations for all studied sites are very high $(2.880 \pm 1.160208 \mathrm{ppm})$, near the

\section{Volume 4 Issue 12, December 2015}




\section{International Journal of Science and Research (IJSR) \\ ISSN (Online): 2319-7064 \\ Index Copernicus Value (2013): 6.14 | Impact Factor (2014): 5.611}

values of standard reference materials (SRM) for IAEA. The high Fe value confirms with the fact that the soil is clay. The high concentration of Fe clay soils can not cause any risks, because $\mathrm{Fe}$ is not a contaminant element. Fe is important in plant nutrition and an essential crop micronutrient, while most the $\mathrm{Cr}, \mathrm{Ni}, \mathrm{Cu}, \mathrm{Zn}, \mathrm{Pb}, \mathrm{Co}, \mathrm{Fe}, \mathrm{Zr}, \mathrm{Y}, \mathrm{Rb}$ and $\mathrm{V}$ concentrations are $(0.4245,0.1331,0.0435,0.0127,0.0027$, $0.0011,2.7521,277.547,16.4618,72.6376$ and 47.7802) (ppm) respectively

Table 2: Descriptive Statistics Report

\begin{tabular}{|c|c|c|c|c|c|c|c|c|c|c|c|}
\hline & $\begin{array}{c}\mathrm{Cr} \\
(\mathrm{ppm})\end{array}$ & $\begin{array}{c}\mathrm{Ni} \\
(\mathrm{ppm})\end{array}$ & $\begin{array}{c}\mathrm{Cu} \\
(\mathrm{ppm})\end{array}$ & $\begin{array}{c}\mathrm{Zn} \\
(\mathrm{ppm})\end{array}$ & $\begin{array}{c}\mathrm{Pb} \\
(\mathrm{ppm})\end{array}$ & $\begin{array}{c}\mathrm{Co} \\
(\mathrm{ppm})\end{array}$ & $\begin{array}{c}\mathrm{Fe} \\
(\mathrm{ppm})\end{array}$ & $\begin{array}{c}\mathrm{Zr} \\
(\mathrm{ppm})\end{array}$ & $\begin{array}{c}\mathrm{Y} \\
(\mathrm{ppm})\end{array}$ & $\begin{array}{c}\mathrm{Rb} \\
(\mathrm{ppm})\end{array}$ & $\begin{array}{c}\mathrm{V} \\
(\mathrm{ppm})\end{array}$ \\
\hline Mean & 0.4245 & 0.1331 & 0.0435 & 0.0127 & 0.0027 & 0.0011 & 2.7521 & 277.548 & 16.4618 & 72.6376 & 47.7802 \\
\hline Std. Deviation & 1.9812 & 0.6332 & 0.1728 & 0.0337 & 0.0025 & 0.0026 & 5.6838 & 175.198 & 6.135 & 30.708 & 13.148 \\
\hline Variance & 3.9250 & 0.4010 & 0.0300 & 0.0010 & 0.0000 & 0.0000 & 32.306 & 30694.3 & 37.646 & 943.013 & 172.871 \\
\hline Geometric Mean & 0.0252 & 0.0000 & 0.0000 & 0.0041 & 0.0000 & 0.0000 & 1.5110 & 242.873 & 15.563 & 61.3784 & 46.0348 \\
\hline Range & 9.7140 & 3.1060 & 0.8520 & 0.1660 & 0.0080 & 0.0080 & 29.1190 & 753.446 & 21.554 & 149.608 & 42.929 \\
\hline Std. Error of Mean & 0.4044 & 0.1293 & 0.0353 & 0.0069 & 0.0005 & 0.0005 & 1.1602 & 35.762 & 1.252 & 6.268 & 2.6838 \\
\hline Minimum & 0.0120 & 0.0000 & 0.0000 & 0.0000 & 0.0000 & 0.0000 & 0.0590 & 105.514 & 9.666 & 4.713 & 27.675 \\
\hline Maximum & 9.7260 & 3.1060 & 0.8520 & 0.1670 & 0.0080 & 0.0080 & 29.1780 & 858.960 & 31.220 & 154.321 & 70.604 \\
\hline
\end{tabular}

Table 3: Comparison of trace element concentrations (in ppm) for studied samples with other studies in different locations from the world

\begin{tabular}{|c|c|c|c|c|c|c|c|c|c|c|}
\hline Element & $\begin{array}{c}\text { Karon } \\
\text { Lake*[13] }\end{array}$ & $\begin{array}{c}\text { Wadi El } \\
\text { Rayan[13] }\end{array}$ & $\begin{array}{c}\text { Marmara } \\
\text { Sea [14] }\end{array}$ & $\begin{array}{c}\text { Gulf of } \\
\text { Naples[15] }\end{array}$ & $\begin{array}{c}\text { Saros } \\
\text { Gulf[16] }\end{array}$ & $\begin{array}{c}\text { (ISIW) at } \\
\text { Romania[17] }\end{array}$ & $\begin{array}{c}\text { Hyderabad, } \\
\text { India [18] }\end{array}$ & $\begin{array}{c}\text { Threshold } \\
\text { value[19] }\end{array}$ & $\begin{array}{c}\text { Tirana,Sediment } \\
\text { sample[20] }\end{array}$ & $\begin{array}{c}\text { Haweja } \\
\text { Kirkuk[21] }\end{array}$ \\
\hline $\mathrm{Cr}$ & $26-98$ & $23-203$ & $65-85$ & $11-66$ & $35-75$ & $52.9-101.3$ & $12.3-480.6$ & $10-50$ & - & - \\
\hline $\mathrm{Ni}$ & $9-46$ & $14-18$ & $35-50$ & $0.01-26.7$ & $<5-75$ & $41.9-65.6$ & $12.6-132.0$ & $10-50$ & - \\
\hline $\mathrm{Cu}$ & $34-46$ & $43-52$ & $20-80$ & $3-664$ & $<0.5-48$ & $<15-52.8$ & $11.1-186.6$ & $10-40$ & - & - \\
\hline $\mathrm{Zn}$ & $25-90$ & $60-145$ & $77-1765$ & $25-120$ & $-0-$ & $40.8-882.2$ & $20-200$ & $60-145$ & - & - \\
\hline $\mathrm{Pb}$ & $\mathrm{u} . \mathrm{d}-17$ & - & - & - & - & $11.0-52.2$ & $42.9-1832.5$ & $10-30$ & - \\
\hline $\mathrm{Co}$ & - & - & - & - & - & - & - & - & - & - \\
\hline $\mathrm{Fe}$ & - & - & - & - & - & - & - & - & 4.39 & 1.55 \\
\hline $\mathrm{Zr}$ & $79-231$ & $98-737$ & - & - & - & - & - & - & - & - \\
\hline $\mathrm{Y}$ & $11-34$ & $9-38$ & - & - & - & - & - & $100-1000$ & - & - \\
\hline $\mathrm{Rb}$ & $16-51$ & $18-25$ & - & - & - & - & - & - & - & - \\
\hline $\mathrm{V}$ & $7-57$ & $11-17$ & - & - & - & $95.5-110.7$ & - & $30-150$ & - & - \\
\hline
\end{tabular}

-Not limited

Table 4: Person Correlation matrix of selected major and trace elements for soils samples-Nyala city

\begin{tabular}{|c|c|c|c|c|c|c|c|c|c|c|c|}
\hline Element & $\mathbf{C r}$ & $\mathbf{N i}$ & $\mathbf{C u}$ & $\mathbf{Z n}$ & $\mathbf{P b}$ & $\mathbf{C o}$ & $\mathbf{F e}$ & $\mathbf{Z r}$ & $\mathbf{Y}$ & $\mathbf{R b}$ & $\mathbf{V}$ \\
\hline $\mathbf{C r}$ & 1 & & & & & & & & & & \\
\hline $\mathbf{N i}$ & -.043 & 1 & & & & & & & & & \\
\hline $\mathbf{C u}$ & $.997^{* *}$ & -.051 & 1 & & & & & & & & \\
\hline $\mathbf{Z n}$ & $.975^{* *}$ & -.054 & $.971^{* *}$ & 1 & & & & & & & \\
\hline $\mathbf{P b}$ & -.230 & -.056 & -.235 & -.054 & 1 & & & & & & \\
\hline $\mathbf{C o}$ & -.091 & -.090 & -.091 & -.011 & .204 & 1 & & & & & \\
\hline $\mathbf{F e}$ & $.990^{* *}$ & -.032 & $.987^{* *}$ & $.982^{* *}$ & -.167 & -.030 & 1 & & & \\
\hline $\mathbf{Z r}$ & -.129 & .020 & -.105 & -.109 & .078 & .018 & -.088 & 1 & & & \\
\hline $\mathbf{Y}$ & -.106 & .085 & -.085 & -.021 & .239 & .100 & -.056 & $.874 * *$ & 1 & & \\
\hline $\mathbf{R b}$ & -.029 & .017 & -.039 & .042 & $.459^{*}$ & .385 & .018 & -.073 & .077 & 1 & \\
\hline $\mathbf{V}$ & -.131 & .080 & -.149 & -.028 & $.447^{*}$ & .110 & -.058 & .226 & .322 & .017 & 1 \\
\hline
\end{tabular}

**. Correlation is significant at the 0.01

\section{Conclusions}

XRF technique has been employed in order to reveal their mineral composition to evaluate the pollution of soil with heavy metals. The concentrations of studied elements $(\mathrm{Cr}$, $\mathrm{Ni}, \mathrm{Cu}, \mathrm{Zn}, \mathrm{Pb}, \mathrm{Co}, \mathrm{Fe}, \mathrm{Zr}, \mathrm{Y}, \mathrm{Rb}$ and $\mathrm{V}$ ) in Nyala city were determined. A soil pollution assessment becomes very complex when different sources of contamination are present and their products are variably distributed with time assembling and become toxic. As a result of existance of all these elements, which are not pollutant, we recommend that the measurement of heavy metals in study area are within acceptable levels and doesn't possess any biological risks. The results of this study can be used as a data baseline for preparing a radiological map of the study area, especially at the chosen sites. Existance of toxic elements with different values caused many diseases if reached to human bodies with high ratio [21]. For example, $\mathrm{Cr}$ caused carcinoma; $\mathrm{Cu}$ caused cirrhosis, nausea, vomiting and diarrhea.

\section{Reference}

[1] Fergusson, JE., editor. The Heavy Elements: Chemistry, Environmental Impact and Health Effects. Oxford: Pergamon Press; 1990.

[2] Duffus JH. Heavy metals-a meaningless term? Pure Appl Chem. 2002; 74(5):793-807.

\section{Volume 4 Issue 12, December 2015}




\section{International Journal of Science and Research (IJSR) \\ ISSN (Online): 2319-7064 \\ Index Copernicus Value (2013): 6.14 | Impact Factor (2014): 5.611}

[3] Bradl, H., editor. Heavy Metals in the Environment: Origin, Interaction and Remediation Volume 6. London: Academic Press; 2002.

[4] He ZL, Yang XE, Stoffella PJ. Trace elements in agroecosystems and impacts on the environment. $\mathrm{J}$ Trace Elem Med Biol. 2005; 19(2-3):125-140. [PubMed: 16325528]

[5] A.S. Alaamer, "Assessment of Human Exposures to $\mathrm{Na}$ tural Sources of Radiation in Soil of Riyadh, Saudi Arabia," Turkish Journal Engineering Environmental Sci- ences, Vol. 32, No. 4, 2008, pp. 229-234.

[6] A.A. A. Mageed, "Effect of Some Environmental Factors on the Biodiversity of Holozooplankton Community in Lake Qarun, Egypt," Egyptian Journal of Aquatic Re- search, Vol. 31, No. 2, 2005, pp. 230-234.

[7] A.H. Meshal, "The Problem of the Salinity Increase in Lake Qarun (Egypt) and a Propose Solution," Journal Conceal International Pour l'Exploration de la Mer, Vol. 37, No. 2, 1977, pp. 137-143.

[8] P. J. Mehringer, K. L. Petersen and F. A. Hassan, “A Pollen Record from Birket Qarun and the Recent History of the Fayum, Egypt," Quaternary Research, Vol. 11, No. 2, 1979, pp. 238-256. doi:10.1016/00335894(79)90006-1

[9] K. Norrish and B. W. Chappell, "X-Ray Fluorescence Spectrography," In: J. Zussman, Ed., Physical Methods of Determinative Minerology, Academic press, New York, 1966, pp. 161-214.

[10] Monitorul Oficial al Romaniei No. 303 bis/ 6 XII 1997/ OM 756 (1997).

[11] Buchanan - smith e.al 2011

[12] Norrish and Chappell, 1966

[13] Samia M. El-Bahi et al. accepted June 5, 2013

[14]E. Antoaneta, A. Bosneaga and L. Georgescu, "Determi- nation of Heavy Metals in Soils Using XRF Technique," Romanian Journal of Physics, Vol. 55, No. 7-8, 2009, pp. 815-820.

[15] S. Akyuz, T. Akyuz, A. O. Algan, N. M. Mukhamedshina and A. A. Mirsagatova, "Energy Dispersive X-Ray Fluo- rescence and Neutron Activation Analysis of Surficial Se- diments of the Sea of Marmara and the Black Sea around Istanbul," Journal Radioanalytical and Nuclear Chemis- try, Vol. 254, No. 8, 2002, pp. 569-575. doi:10.1023/A:1021606608862

[16] rescence and Neutron Activation Analysis of Surficial Se- diments of the Sea of Marmara and the Black Sea around Istanbul," Journal Radioanalytical and Nuclear Chemis- try, Vol. 254, No. 8, 2002, pp. 569-575. doi:10.1023/A:1021606608862.

[17] E. Romano, A. Ausili, N. Zharova, M. C. Mango, B. Pavoni and M. Gabellini, "Marine Sediment Concentration of an Industrial Site at Port of Bagnoli, Gulf of Naples, Southern Italy," Marine Pollution Bulletin, Vol. 49, No. 5, 2004, pp. 487-495. doi:10.1016/j.marpolbul.2004.03.014

[18] N. N. Vandana Partha, Murthya and P. R. Saxena, "Assessment of Heavy Metal Contamination in Soil around Hazardous Waste Disposal Sites in Hyderabad City (India) Natural and Anthropogenic Implications," Environmental Research and Management, Vol. 2, No. 1, 2011, pp. 27- 34 .
[19]D. C. Adriano, “Trace Elements in Terrestrial Environments," Biogeochemistry, Bioavailability, and Risks of Metals, 2nd Edition, Springer Verlag, New York, 2001

[20]FATON MALOKU1, Maloku F. et al., 2015, Albanian j. agric. sci. 2015;14 (2):137-148

[21] Ismail,S.A.,(2004): Atmospheric pollution and environmental effect in Kirkuk area,Iraq,6th intern.conf. on geochemistry, Alex.univ.Egypt,15- 16 sept.pp.23-29. 